$\xi=-1$

\title{
Pedagogical Technologies in Legal Education: Historical Analysis and Modern Experience
}

\author{
Evgenia Sagalaeva, Irina Komarevceva, Olga Landina, Marina Melnichuk, Svetlana Mukhametova \\ North-Caucasian Federal University, 355009, Russia, Stavropol, Pushkina St., 1
}

\begin{abstract}
The article is dedicated to research and analysis of the issues of formation and development of pedagogical technologies in legal education. The historical experience of training of legal human resources both in Russia and in foreign countries is investigated. Special attention is paid to the enchiridia of M. Psellus. The theoretical and practical problems that affect the application of pedagogical technologies in legal education at the present stage are analyzed. The potential of problematic training in the context of legal education is revealed. The scientific novelty of the work is that the authors on the basis of studying the history of the formation and development of pedagogical technologies both in Russia and abroad attempted to determine the main trends in the development of this sphere of social relations and to justify the most constructive proposals in order to improve the training of graduate lawyers.
\end{abstract}

Keywords: legal education, pedagogic, pedagogical technologies.

\section{Introduction}

At the present stage of the development of Russian legal education, which is characterized by the practical implementation of the standards of the third generation standard, the main objective of the educational process is the implementation of the competence approach, which is the basis of the educational standard, the formation of competencies. In this regard, the issue of pedagogical technologies that can lead to the result stated in the new educational standard is actualized. Modern Russian legal education requires the use of pedagogical technologies that can solve the problems of teaching students the skills of independent search and mastering of knowledge that give students the opportunity to form knowledge about their ignorance [1]. In this regard, special attention is paid to the issue of ways to implement such pedagogical technologies in the modern Russian educational environment. It is possible to borrow foreign experience in training law students, including the American experience, where the technique of working out the professional competencies has been sharpened for a long period [2].

Studying the history of the application of pedagogical technologies is an important and necessary component of the ongoing process of their modernization and improvement. The historical approach is manifested in the direction of scientific knowledge from modernity to the past, which determines its retrospective character [3]. The principle of historicism in pedagogical research means the consideration of existing pedagogical phenomena, for example, pedagogical technologies, not only in terms of their present but also from the position of their past and future.

\section{Methods}

In the course of work under this article, such scientific methods of research as historical, dialectical, logical and method of compara- tive research were used. The historical method was used mainly in studying the history of the development of pedagogical technologies in legal education. The dialectical method provided an opportunity to study the mechanism of applying pedagogical technologies in legal education in development, communication, and interaction with other pedagogical phenomena. The logical method is used, in particular, in the study and analysis of individual pedagogical technologies used in legal education. The method of comparative research allowed the authors to analyze and compare the foreign and Russian experience of preparing qualified legal human resources.

\section{Results}

\subsection{Legal Education and Pedagogical Technologies in the Ancient Period}

The rudiments of legal education can be found in the era of the Ancient World. Thus, in ancient Rome, the study of law was an element of the education of the child. According to Robert, the formation of children started when the child reached the age of seven. In patriarchal Roman families, fathers were engaged in the education of children. Children were taught many subjects, including law. Children who have reached the age of sixteen could get "the highest stage" of education. In ancient Rome, there were higher schools, which gave special education in the field of law [4]. During the considered period, a lot of attention was paid to education. So, the great contribution to the development of education was made by the ideas expressed by Cicero. Many of his works were devoted to the problems of education, including such works as "On the orator", "Orator", "Brutus". In ancient Rome, the study of rhetoric prevailed, but many figures of the time, for example, Cato the Elder, advocated the introduction of "specific Italian courses", in particular, by law [5]. 
With some degree of conventionality, one can speak of the formation of pedagogical technologies used in the educational process in ancient Rome. The enormous influence on them was brought by the education system of Ancient Greece: The Academy of Plato, Aristotle's Lyceum and Socrates' rhetoric school. So, Socrates preferred regular lectures, and Plato - a group dialogue or seminar. In the field of law study, it is necessary to note such a method of cognition as memorizing by heart of the legal texts, for example, the texts of laws of the XII tables (mid-5th century BC). In the context of studying the issue of the formation and development of pedagogical technologies in legal education, the enchiridia (textbook) entitled "The Synopsis of Laws", written in XI by Byzantine scholar Michael Psellus, is of great interest. A detailed analysis of these enchiridia is presented in one of the modern educational courses on pedagogy [6]. This work is noteworthy because it was addressed to a specific student - the heir to the Byzantine throne, the eldest son of the emperor Constantine X Doukas - Michael.

The manual "The Synopsis of Laws" as a means of teaching and upbringing differed in a number of features. First, it ensured the harmonization of the cognitive interests and needs of both the teacher and the student. Second, its content was of a humanistic nature. Third, it was aimed at the versatile education of the student with reliance on humanitarian knowledge.

With regard to the pedagogical technology applied by Psellus, the use of problematic training should be mentioned: Psellus used problem situations to develop a student's professional thinking of the student. Great attention was also paid to the culture of speech. The method of dialogue was used, so the student was at the center of attention. The student was regarded as a developing personality, and sufficient attention was paid to his intellectual development. It should be mentioned that the uniqueness of Psellus's enchiridia is that his author already knew in advance the personal characteristics of his future student. In other words, Psellus's textbook took into account the knowledge, skills, abilities, and other personal characteristics of the student. Nowadays, textbooks can be personal-oriented (for example, for children suffering from certain diseases), but still they are designed for the use in a particular group of students, even if only a few. In this regard, academic teachers, in particular, N.I. Sokurova, mention that these enchiridia are the most productive tool in the process of education, training and development of the student [7]. As a result, one can note that the methods used by Psellus were of a humanistic nature; they were personality-oriented.

A brief examination of some fragments of the process of teaching of law in ancient Rome and Byzantium makes it possible to suggest the use of certain pedagogical technologies in the process of learning. So, it is possible to talk about the application of problematic training (mastering the educational material through the example of problem situations). The teaching of law implied the mastering of other sciences forming an intellectually developed, harmonious personality. The training was of a secular nature.

\subsection{Legal Education and Pedagogical Technologies in Prerevolutionary Russia}

Let us consider the domestic experience of applying pedagogical technologies in legal education. The starting point in the development of Russian legal education is considered to be the 18th century when two universities were founded - Moscow (1755) and St. Petersburg (1724). In 1803 in Yaroslavl, a profile educational institution was opened - Demidov Legal Lyceum. At that time, legal education was based on such ideological principles as orthodoxy, nationality and autocracy. At the same time, the main role in the development of university education in Russia was played by the state. Based on the West European concept of the university, Russian universities were gradually involved in the state apparatus. Russian legal education of the second half of the 18th century was characterized by the dominance of the natural-legal doctrine since its own legal science was still in the process of development. Thus, at Moscow University, the study of Russian law amounted to the development of military and naval units. Educational literature was built according to a compilation type and started to appear only in the late 18th century.

At the beginning of the 19th century, legal education still remained focused on the philosophical and natural-legal basis. However, the legal education did not stand still: new educational institutions were opened (in Vilnius and Tartu). In 1802, a special state body responsible for education was the Ministry of Education. Within the structure of the established universities, instead of faculties of law, there were so-called "moral and political departments". In Tartu University, the goal of legal education was seen as follows: to make students the defenders of "the rightness of fellow citizens and oppressed innocence".

In 1804, a general University Charter was approved, which provided a kind of "standard" of education in the moral and political department. Among the subjects studied, there were practically no disciplines involving the development of national law. The preference was given to theology and the law of foreign states. However, there was a gradual withdrawal from natural law. The University Charter, adopted in 1835, did not contain an indication of the need to study natural law.

Great influence on the development of legal education was brought by the codification conducted at the beginning of the 19th century under the leadership of M.M. Speransky, which resulted in the publication in 1832-1835 of the Code of Laws of the Russian Empire. As a result of this event, interest in domestic law revived in the country. Moral and political education has, in fact, become legal, which was secured in the Charter of 1835. Especially the change of curricula should be mentioned: theoretical disciplines became closer to the needs of law enforcement practice. Thus, a new model of legal education, dogmatic, was created, which was aimed at a broadcast of a certain amount of knowledge about existing laws to students. The curriculum of law faculties was built on the basis of the Code of Laws; it included many branches of legal disciplines and minimum of philosophical and historical subjects. The essence of such legal education could be defined as "jurisprudence". The content of applied pedagogical technologies was, as a whole, reduced to memorizing the text of the law.

The adoption in 1863 of a new University Charter marked the transition to a new - fundamental - model of legal education. Fundamental legal education was required in the context of ongoing legal reforms (judicial reform of 1854, etc.). Graduate lawyers ought to have developed legal thinking and be able to adapt to rapidly changing legal realities. In this regard, during training, more attention had to be paid not to legal dogma, but to legal principles, its historical foundations. In this regard, the curriculum included the subjects of the philosophical and historical cycle, their share increased; sectoral disciplines were less than $50 \%$ of the total number [8]. With all the progressive nature of fundamental legal education, one can mention its shortcomings - the study of general disciplines in the prejudice of special training.

The University Charter of 1884 contributed to a harmonious combination of fundamentalism and restrained utilitarianism in legal education, "brought together" the theory and practice of jurisprudence. The new model of legal education lasted until 1917.

\subsection{Legal Education and Pedagogical Technologies in the Soviet Time}

Pedagogical technologies used in the Soviet period should be characterized on the basis of trends in the development of Soviet legal education. So, in the first years of Soviet power, the legal school that had been formed before the revolution was convicted in scholasticism, it was accused of preparing soulless officials for the purpose of oppressing the working class. In this regard, legal faculties of many universities, including the Kazan University, 
were massively closed, which eventually led to practical annihilation of the existing system of legal education. Instead of law faculties, faculties of social sciences were created. The curricula of Soviet law institutes and faculties underwent significant adjustment; many fundamental disciplines were excluded, for example, Roman law, which, in the opinion of Soviet educators and scientists, was of a bourgeois nature [9]. Legal education turned out to be of the applied nature.

It should also be mentioned that legal education in that period was greatly influenced by the assertion of the ideology of Marxism as official, which determined not only the correction of curricula, as mentioned above, but also the change in the structure of teaching of both social science and legal disciplines. Regarding the special political and economic situation in the country, new subjects appeared in the curriculum on jurisprudence: working law, the history of working legislation, state control, cooperative law, etc. At the same time, the process of "cutting" university legal education was gradually proceeding; law faculties at universities were closed every year. In 1924, this process reached the Don University. In the literature, the ongoing process of liquidation of higher legal education is explained by the fact that jurisprudence was considered by the Soviet authorities as a "servant" of the tsarist regime that oppressed the working class [10].

The amount of the share of trained lawyers in higher professional education was negligibly small - no more than $1.5 \%$. The number of law students trained in the USSR in the international context against the background of developed world states also was not large enough [11].

The process of formation of a new Soviet system of legal education was thorny. On the one hand, Soviet authorities were not satisfied with prerevolutionary law professors, since they were regarded as carriers of bourgeois ideology alien to the new order. On the other hand, the Soviet law school had not yet managed to prepare its own scientific and pedagogical staff. In this regard, in the initial period, the Soviet authorities still had to involve prerevolutionary teachers in the educational process. Against this background, numerous short-term legal courses were organized.

Pedagogical technologies used in the considered period (1920s1930s) were characterized by the system of legal education existing at that time. Let us consider the elements of pedagogical technologies used in the legal education of the Soviet state. In the prewar period, a great emphasis was put on the formation of a correspondence course of study in legal disciplines. Due to the policy pursued by the state, the number of students enrolled in the legal profession gradually increased. By the beginning of the 1940s, after the merger of the Higher Law Academy and the AllUnion Correspondence Institute of Law, there were already 7670 of them. A sharp increase in the number of law students gave rise to a number of additional problems. Plainly, there was not enough academic space. In this regard, the educational process had received a negative coloration: free attendance was introduced, current monitoring of progress was abolished. All this had negative impact on the quality of the preparation of students who began to skip classes, which led to a decrease in the academic discipline. A special feature of Soviet legal education was the system of secondary legal education, which in the literature was called "an interesting form of profanity of legal education" [12]. From the organizational point of view, this form of training was represented by the Central Correspondence Law School of People's Commissariat of Justice of RSFSR created in 1936. The activity of the said educational institution was characterized by a disorderly nature of functioning. Such concepts as "pedagogical process", "pedagogical technologies" could hardly be applied in the context of the activities of correspondence schools of law. Training sessions were held only in the two union republics - Russian and Ukrainian. Such a form of training as the consultations of the listeners was not conducted at all. Students performed slightly more than $20 \%$ of written works, and in some schools, no work was performed. However, at the highest level, there were attempts to optimize the activities of the Central Correspondence Law School in order to increase its effectiveness. A key role in the regulation of educational activity was played by the Statute on Correspondence Legal Schools, adopted in 1939, in which all the elements of the educational process were regulated in detail: lectures, seminars, tests, consultations and examinations. The People's Commissariat of Justice tried to introduce daily monitoring of the activities of teachers. Steps were taken to improve the methodological support of the educational process. However, despite this, the level of legal education of students left much to be desired. So, the future servants of the law lacked elementary literacy. As for the content of pedagogical technologies, it was primitive. The teachers suggested the students to literally rewrite the text of the textbook. Based on such written works, the students were evaluated.

As an intermediate conclusion, one can mention that the pedagogical technologies applied in the 1920s-1930s in the training of law students were influenced by many factors: political, economic, social, and legal. Legal education was carried out against the background of the main goal of that time - to increase the number of students in accordance with the plan of 1935. There was a shortage of pedagogical personnel, educational literature, and educational facilities. The educational process was strictly regulated "from above". The quality of students' knowledge was low. The level of development of pedagogical technologies was below the normal.

In the post-war period, legal education was carried out mainly in the extramural form of study. The substantive characteristics of extramural education in law and the practice of its implementation could not fully contribute to the formation of loyalty to legal values among legal students.

In addition, the politicization and nationalization of Soviet legal science and education led to the flourishing of legal positivism, under which the law was equated with the legal norm [13]. Law students were taught to comment on the current legislation. These circumstances negatively affected both the state of Soviet legal science and the quality of training of law students.

\subsection{The Modern Stage of Development of Legal Educa- tion and Pedagogical Technologies}

Of interest is the issue of the use of pedagogical technologies in the "transition" period, characterized by the emergence of the modern Russian system of legal education. One of the authors of this work received higher legal education at the time of the transformation of Soviet legal education into the Russian one. It happened in 1993-1998. Within the context of the issue of pedagogical technologies used at the present time (for example, the SSPI, SSPU, SSU), it is required to focus on external factors that have influenced their application. During this period, many legislative acts of the Soviet period (the Civil Code of the RSFSR, the Criminal Code of the RSFSR, etc.) were still in force; however, gradually, in 1994-1996, the legislative base was updated, Russian legal acts were adopted. It is clear that educational and scientific literature, adequately reflecting the content of new legislative acts, was missing. In the process of learning, not only the students got knowledge, but also the teachers. In this regard, the student was required, first of all, to get acquainted with the content of the normative act, which proves the elements of legal positivism inherent in the Soviet education system.

The current period of the development of Russian legal education is characterized by a large-scale reform, which is based on three mutually conditioned factors. First, Russia's accession to the Bologna Declaration in 2003 requires fulfillment of its respective obligations. Second, the adoption of the FSES of the third generation significantly changed the concept of modern legal education; its structure, principles and content were updated. Third, the implementation of the provisions of the Presidential Decree of May 26, 2009 "On measures to improve the quality of legal education" [14]. At first glance, the publication of the Decree was called by the reasons of the internal nature: unreasonable growth in the 
number of legal institutions of higher education, the training of low-qualified lawyers, the reduction in the requirements for the quality of education, or a direct violation of these requirements. However, similar circumstances can be observed not only on the national, but also on the international scene: in the international aspect, there is education of a "mass" nature, including legal education, which draws the attention of Professor of the Law School of the University of Chicago - Eric Posner [15]. Besides, the segment of private education is expanding; there is a weak correlation between the professional profile of graduates and the needs of the market for specialists. Thus, the factors mentioned above, which determine the direction of development and reform of the domestic higher legal education, have been formed under the influence of new realities of the international scale.

In the current conditions for the development of legal education, updating of the applied pedagogical technologies is required. At the present stage, a graduate lawyer who is able to quickly adapt to changing external factors (legal, social, economic, etc.) enjoys "demand" in the labor market, but he/she must be communicative and have "flexible" thinking. In this regard, Troitskaya is absolutely right; she speaks of the ineffectiveness of using traditional reproductive education, in which the student only remembers and reproduces information [16]. The authors believe that the pedagogical technologies used in modern legal education should be aimed at the development of the personality of the student, the formation of his/her skills of creative processing of the received information, and the stimulation of his/her selfdevelopment.

\section{Discussion}

The professional competence approach underlying the modern legal education presupposes the formation of professional skills in the law student lawyer in the course of training [17]. When solving this problem, teachers are guided not only by general pedagogical principles but also use innovative and interactive techniques, including the technology of problematic studying. Taking into account the thesis stated in the literature that the solution of problems is what lawyers do, the authors believe that the practice of applying problem-based learning technologies in legal education not only allows involving students in the process of cognition, but also contributes to the development of research skills, formation of professional competencies [18].

The modern concept of problematic training is based on the works of the famous American philosopher, psychologist, and educator J. Dewey, who at one time justified the need during the educational process to actively use the research method and concentrate on solving "casus" problems [19, 20].

The technology of problem-based learning is not a novel of modern pedagogical knowledge; it was discussed in the last century. A special contribution to the development of this technology was made by M.I. Makhmutov [21].

The essence of problem training is the management of the cognitive activity of the person. It is based on the principle that a deep and firm assimilation of knowledge is possible when posing a problem in which the learner must directly participate. Only under this condition, they actively perceive the educational information, and the solution of the problem becomes creative, ensuring the formation of genuine professional skills. In this regard, the method of problem training should be understood as an organization of the educational process, which includes the creation of a problematic (search) situation that excites in the students the need to solve emerging problems that involve them in independent cognitive activity [22].

Special means, methods of problem training, used in the system of legal education, are case study and clinical training.

Problem training can be implemented both within the framework of lectures and in practical exercises. Talking about a problematic lecture, its successful conduct requires teaching not only by the teacher, but also by the student. The student should prepare for a problematic lecture, study special literature, especially monographic, regulatory and legal acts and materials of law enforcement practice. A suitable form of conducting a problematic lecture is a dialogue with participants - the teacher and students. This technology is undeniably laborious but very effective: the result of its application is the development of students' skills and public speaking skills in front of the audience, which is important in legal activities; students develop skills of independent professional activity; there is a process of assimilation of legal norms, doctrinal regulations, and judicial precedents. The technology of problematic training is actively used within the Law Institute of NorthCaucasus Federal University. Thus, when reading the course of lectures on the disciplines of various departments of the Law Institute for the bachelor students, the teachers, including the authors of this article, recommend students to get acquainted with the scientific work of the faculty of the corresponding department of the Law Institute of North-Caucasus Federal University [23, 24, 25].

The technology of problematic training, which is used at the present stage in the system of higher legal education, assumes a change in the nature of the interaction between the teacher and the student. In this regard, today, authoritarian pedagogical technologies, which in literature are also called "violent pedagogy", are absolutely unacceptable. In this case, the teacher in the learning process dominates the student, suppresses his/her will, initiative and independence. The authoritarian educational process is characterized by stress, frequent conflict situations, is based on power relations, ignores the personal characteristics of students [26].

Despite the complexity of preparing and conducting classes using problematic pedagogical technologies, their advantages are obvious: they are effective, allow students to "dip" into the professional environment, and help them to form the required professional competencies.

At the same time, the optimal correlation between the theoretical and practical components in the process of legal education should be remembered. Bends in one or another direction can adversely affect the final "product" of legal education - a graduate of a legal university. So, David Segal in his article published in "The New York Times", referring to legal universities, asks "Why do not they teach law students?" The author, in particular, notes that in law schools much attention is paid to the study of theoretical aspects of law, including features of property rights in England of the post-feudal period, but the students are not taught to apply the existing law in practice [27]. The reasonable application of problematic training technologies in the educational process will allow avoiding the situation described by D. Segal.

\section{Conclusion}

As a result of the research carried out on the peculiarities of the use of pedagogical technologies in legal education, it should be mentioned that over time they have changed under the influence of various factors: political, economic, and legal. Of course, to a large extent, the pedagogical technologies used in legal education were conditioned by the social order; they depended on which "product" would be in demand in the labor market.

The use of pedagogical technologies in legal education at the present stage is largely conditioned by the educational policy pursued by the state today. The specificity of the application of pedagogical technologies in legal education is based on new educational standards adopted in the development of the provisions of the Bologna Declaration. A special place among the technologies applied today in legal education is assigned to problem-based education. This feature is typical for both Russian and foreign legal education. 


\section{References}

[1] N.A. Solovyeva, Kompetentnostnyi podkhod v yuridicheskom obrazovanii: problemy i perspektivy [Competence Approach in Legal Education: Problems and Prospects], Vestnik VolGU, Seriya 6 14 (2013) 43.

[2] M.L. Davydova, Obuchenie yuridicheskoi professii v Rossii i SShA: k voprosu ob universalnykh osnovaniyakh [Training for the Legal Profession in Russia and the USA: To the Issue of Universal Foundations], Pravo i sovremennye gosudarstva 2 (2013) 33.

[3] D.A. Shigal. Teoriya istoriko-pravovogo sravnitelnogo metoda [Theory of the Historical-Legal Comparative Method] https://cyberleninka.ru/article/n/teoriya-istoriko-pravovogosravnitelnogo-metoda. Revised 2013. Accessed July 6, 2018.

[4] Zh.-N. Robert, Rim [Rome], Moscow, 2006, pp. 333-334.

[5] M. Grant, Rimlyane. Tsivilizatsiya Drevnego Rima [The Romans. Civilization of Ancient Rome], Moscow, 2005, p. 98.

[6] K.M. Levitan, Yuridicheskaya pedagogika: uchebnik [Legal Pedagogy: Textbook], Moscow, 95-100.

[7] N.I. Sokurova, Individualnyi podkhod kak unikalnyi stil obucheniya v kontekste gumanisticheskikh paradigmalnykh orientatsii obrazovaniya Srednevekovya [Individual Approach as a Unique Style of Training in the Context of Humanistic Paradigm Orientations of Middle Ages' Education], Pedagogicheskoe obrazovanie v Rossii 12 (2014) 27.

[8] V.V. Zakharov, Modernizatsiya yuridicheskogo obrazovaniya v rossiiskikh universitetakh $\mathrm{v}$ seredine XIX stoletiya [Modernization of Legal Education at Russian Universities in the Middle of the 19th Century], Yuridicheskoe obrazovanie i nauka 4 (2003)

[9] A.Ya. Vyshinsky, Osnovnye zadachi nauki Sovetskogo Sotsialisticheskogo prava [The Main Tasks of the Science of Soviet Socialist Law], Sovetskoe gosudarstvo 4 (1938) 39.

[10] V.M. Shadrin, Teoreticheskaya yurisprudentsiya i yuridicheskoe obrazovanie $\mathrm{v}$ pervye gody sovetskoi vlasti [Theoretical Jurisprudence and Legal Education in the First Years of Soviet Power], Vestnik Chelyabinskogo gosudarstvennogo universiteta 27(281) (2012) 45-49.

[11] B.N. Topornin, Vysshee yuridicheskoe obrazovanie v Rossii: problemy razvitiya [Higher Legal Education in Russia: Problems of Development], Moscow, 1996, pp. 20-21.

[12] A.Ya. Kodintsev, Zaochnoe yuridicheskoe obrazovanie v sisteme organov yustitsii SSSR v 30-e gody XX veka [The Extramural Legal Education in the System of Justice Agencies of the USSR in the 1930s], Nauchnye issledovaniya v obrazovanii 6 (2007) 74-79. https://cyberleninka.ru/article/n/zaochnoe-yuridicheskoeobrazovanie-v-sisteme-organov-yustitsii-sssr-v-30-e-gody-hh-veka. Revised 2007. Accessed July 6, 2018.

[13] A.G. Kalpin, A.I. Maslyaev (eds.), Grazhdanskoe pravo. Chast pervaya: uchebnik [Civil Law. Part One: Textbook], Moscow, 2000, p. 41.

[14] Ukaz Prezidenta RF ot 26 maya 2009 g. "O merakh po povysheniyu kachestva yuridicheskogo obrazovaniya" [Decree of the President of the Russian Federation "On Measures to Improve the Quality of Legal Education” (May 26, 2009)]. RG. https://rg.ru/2009/05/29/uristy-dok.html. Revised May 29, 2009. Accessed July 6, 2018.

[15] E. Posner, The Real Problem with Law Schools. Slate. http://www.slate.com/articles/news and politics/view from chicag o/2013/04/the real_problem with_law schools too_many lawyers .html. Revised April 2, 2013. Accessed July 6, 2018.

[16] I.Yu. Troitskaya, Tekhnologii aktivnogo obucheniya kak sredstvo razvitiya poznavatelnoi motivatsii u studentov [Technologies of Active Learning as a Means of Developing Cognitive Motivation among Students], European Journal of Education and Applied Psychology 2 (2017) 30-32.

[17] V.Ya. Kikot, A.M. Stolyarenko (eds.), Yuridicheskaya pedagogika: ucheb. dlya stud. vuzov, obuch. po spets. 021100 "Yurisprudentsiya" [Legal Pedagogics: Textbook for Students of Universities, Training in Specialty 021100 "Jurisprudence"], UNITY: Zakon i parvo, Moscow, 2004

[18] J. Weinstein, L.H. Morton, Stuck in a Rut: The Role of Creative Thinking in Problem Solving and Legal Education. Scholarly Commons. https://scholarlycommons.law.cwsl.edu/fs/139/. Accessed July 6, 2018.

[19] T.V. Larkina, Tekhnologiya problemnogo obucheniya v professionalnoi podgotovke budushchikh spetsialistov [Technology of Problem Training in the Professional Training of Future Specialists], Vector nauki TGU 1(8) (2012) 198.
[20] E.F. Tomina, Realizatsiya refleksivnoi kontseptsii Dzh. Dyui v sovremennoi vysshei shkole [Implementation of the Reflexive Concept of J. Dewey in the Modern Higher School], Gumanitarnye nauki, Pedagogika 2(18) (2011) 121

[21] M.I. Makhmutov, Problemnoe obuchenie: osnovnye voprosy teorii [Problematic Training: Basic Issues of Theory], Moscow, 1975.

[22] T.S. Kupavtsev, E.V. Malchenkov, Ispolzovanie metoda problemnogo obucheniya $\mathrm{v}$ uchebno-vospitatel'nom protsesse VUZa MVD Rossii kak sredstvo aktivizatsii samosovershenstvovaniya kursantov i slushatelei [The Use of the Method of Problematic Training in the Educational Process of the University of Russian Ministry of Internal Affairs as a Means of Activating the Self-Improvement of Cadets and Listeners], Uchenye zapiski 9 (2008) 35.

[23] S.N. Medvedev, M.P. Melnikova, M.A. Bichko, S.N. Ivahnenko, V.A. Schegolkov, Possession: Historical and Legal Study in light of RF Civil Code Improvement, Man in India 96(10) (2016) 41194127.

[24] M.I. Tsapko, I.V. Mukhachev, A.S. Gondarenko, N.A. Tkacheva, O.V. Pogozheva, Institutional Changes in the Electoral System in the Contemporary Russia in Light of the Parliamentary Elections in 2016: Methodological, Legal and Doctrinal Aspect, Man in India 96(10) (2016) 3869-3878.

[25] D.A. Smirnov, K.A. Strus, General Scientific Analysis of Implementation of Principles of Law in the Contemporary Russian Legal Basis, Indian Journal of Science and Technology 8(S10) (2015). DOI: $10.17485 / \mathrm{ijst} / 2015 / \mathrm{v} 8 \mathrm{iS} 10 / 84867$.

[26] O.V. Moreva, Pedagogicheskie paradigmy: opyt sistematizatsii [Pedagogical Paradigms: Experience in Systematization], Vestnik Tyumenskogo gosudarstvennogo universiteta 2 (2004). https://cyberleninka.ru/article/n/pedagogicheskie-paradigmy-opytsistematizatsii. Revised 2004 .Accessed July 6, 2018.

[27] D. Segal. What They Don't Teach Law Students: Lawyering. The New York Times. https://www.nytimes.com/2011/11/20/business/after-law-schoolassociates-learn-to-be-lawyers.html. Revised November 19, 2011. Accessed July 6, 2018. 